\title{
Polyovular Follicle
}

National Cancer Institute

\section{Source}

National Cancer Institute. Polyovular Follicle. NCI Thesaurus. Code C123641.

An ovarian follicle that contains more than one oocyte. 